\title{
Mental Disabilities and the Human Right to the Highest Attainable Standard of Health'
}

\author{
Paul Hunt* \& Judith Mesquita**
}

\begin{abstract}
In the majority of countries, the right to health of persons with mental disabilities has been grossly neglected. Necessary healthcare and support services are frequently unavailable or inaccessible, while human rights abuses are often pervasive within services where they do exist. This article explores the right to health as it relates to persons with mental disabilities. It develops an analytical framework for the right to health, derived from General Comment 14 on the right to health of the United Nations Committee on Economic, Social and Cultural Rights; and it applies this framework in the context of mental disabilities. Despite progress in developing appropriate services, additional policy and legislative initiatives are a prerequisite for the realization of the right to health for persons with mental disabilities. A human rights approach, including participation, autonomy, dignity, inclusion, monitoring, and accountability, should guide all relevant actions.
\end{abstract}

* Paul Hunt (M.A., M.Jur.) is Professor of Law and Member of the Human Rights Centre, University of Essex, UK, and Adjunct Professor of Law at University of Waikato, New Zealand. Since 2002, he has held the post of United Nations Special Rapporteur on the right of everyone to the enjoyment of the highest attainable standard of physical and mental health. In 1999-2002, he was Rapporteur of the United Nations Committee on Economic, Social and Cultural Rights.

** Judith Mesquita (M.A., LL.M.) is Senior Research Officer, Human Rights Centre, University of Essex, UK, where she specializes on economic, social, and cultural rights.

1. For convenience, throughout this article, we use the shorthand right to health or right to the highest attainable standard of health to refer to the right of everyone to the enjoyment of the highest attainable standard of physical and mental health. 


\section{INTRODUCTION}

Today, about 450 million people around the world suffer from mental or neurological disorders or from psychosocial problems. ${ }^{2}$ Mental and behavioral disorders are currently estimated to account for 12 percent of the global burden of disease, a figure that is set to increase. ${ }^{3}$ One in every four persons is likely be affected by a mental disorder at some stage of life. ${ }^{4}$

Despite the prevalence of mental disorders, more than 40 percent of countries have no mental health policy; and over 30 percent have no mental health program. "Over 90 percent of countries have no mental health policy that includes children and adolescents." ${ }^{6}$ The mental health budget of most countries is less than 1 percent of their total health expenditure. ${ }^{7}$ Mental healthcare and support services are rarely covered by health insurance. Mental health legislation in some countries is outdated and facilitates, rather than protects against, human rights violations. ${ }^{8}$ In short, mental health is among the most grossly neglected elements of the right to health.

Persons with intellectual disabilities are among the most neglected-the most "invisible" - in our communities. Consistent with this neglect, there are no estimates for the burden of intellectual disabilities, but what evidence there is suggests it is substantial. Intellectual disabilities can place severe personal, economic, and social burdens on both individuals and their families.

Far from providing a supportive environment, care settings are often where human rights abuses occur. This is particularly true in segregated services including residential psychiatric institutions and psychiatric wings of prisons. Persons with mental disabilities are often inappropriately institutionalized on a long-term basis in psychiatric hospitals and other institutions. While institutionalized, they may be vulnerable to: being chained to soiled beds for long periods of time, violence and torture, the administration of treatment without informed consent, unmodified use of electro-convulsive therapy $(\mathrm{ECT}),{ }^{9}$ grossly inadequate sanitation, and inadequate nutrition. ${ }^{10}$

2. World Health Organization (WhO), The World Health Report 2001: Mental Health: New Understanding, New Hope 1 (2001) [hereinafter World Health Report 2001].

3. Id. at 19 .

4. Id. at $\mathrm{x}$.

5. Id. at 3 .

6. Id.

7. Id.

8. WhO, Who Resource Book on Mental Health, Human Rights and Legislation 1 (2005).

9. See, e.g., European Committee for the Prevention of Torture and Inhuman or Degrading Treatment (CPT), The CPT Standards: "Substantive" Sections of the CPT's General Reports 55 (2004), Doc. No. CPT/Inf/E (2002) 1-Rev. 2004.

10. See Mental Disability Rights International (MDRI) \& Asociación Pro Derechos Humanos, Human Rights and Mental Health in Peru 12-14 (2004); Mental Disability Advocacy Centre, Cage Beds: Inhuman and Degrading Treatment in Four EU Accession Countries (2003); Amnesty International, Romania: Memorandum to the Government Concerning Inpatient Psychiatric Treatment (2004). 
Women are particularly vulnerable to sexual abuse and forced sterilizations. ${ }^{11}$ Persons from ethnic and racial minorities are often victims of discrimination in institutions and care systems. A lack of monitoring of psychiatric institutions and weak or nonexistent accountability structures allow these human rights abuses to flourish away from the public eye.

Increased knowledge about mental disabilities and new models of community-based services and support systems have allowed many people with mental disabilities, once relegated to living in closed institutions, to demonstrate that they can live full and active lives in the community. People once thought to be incapable of making decisions for themselves have shattered stereotypes by showing that they are capable of living independently when appropriate legal protections and support services are provided. Moreover, many people once thought to be permanently or inherently limited by a diagnosis of major mental illness have demonstrated that full recovery is possible.

Despite these significant advances, however, people with mental disabilities experience marginalization in all countries. Institutionalization persists in many countries. Elsewhere, community-based services do not always ensure integration, autonomy, and dignity.

In recent years, the human rights of persons with mental disabilities have attracted increasing attention. There is growing jurisprudence in this field, as well as increasing interest from international organizations, civil society, and academics. While attention has traditionally focused on the civil and political rights of persons with mental disabilities, their economic, social, and cultural rights, including the right to health, are also beginning to attract greater attention and concern. ${ }^{12}$

This article has two distinct objectives: First, it seeks to clarify the right to health as it relates to persons with mental disabilities. For this purpose, it draws upon sources including case law, international human rights treaties, and specialized, nonbinding international instruments, such as the recently adopted Montreal Declaration on Intellectual Disability. ${ }^{13}$ While our focus is

11. Karin Raye, Mental Disability Rights Int'l, Violence, Women and Mental Disability (1999).

12. See, e.g., Lawrence Gostin \& Lance Gable, The Human Rights of Persons with Mental Disabilities: A Global Perspective on the Application of Human Rights Principles to Mental Health, 63 MD. L. Rev. 20, 98 (2004); Claire Breen, The Right to Education of Persons with Disabilities: Disabled in Interpretation and Application, 21 NetherLands Q. Hum. RTs. 7 (2003); Purohit and Moore v. Gambia, African Comm'n. on Hum. and Peoples' Rts., Comm. No. 241/2001 (2003); European Committee of Social Rights, Autism-Europe v. France, Complaint No. 13/2002, Decision on the Merits transmitted to the Committee of Ministers on 22 May 2003.

13. Montreal Declaration on Intellectual Disability, adopted 6 Oct. 2004 (Pan-American Health Organization/World Health Organization Conference on Intellectual Disability), available at http://www.aamr.org/pdf/DeclarationMTL.pdf [hereinafter Montreal Declaration]. 
the right to health, we also consider a wide range of human rights of persons with mental disabilities, which are also recognized under international law. Many of these rights both contribute toward, and are dependent upon, the realization of the right to health.

Second, this article develops a common analytical framework that derives from the right to health, and it applies that framework in the context of mental disabilities. Because the right to health is notoriously complex and extensive, it is especially important to develop a common analytical framework that makes the right manageable. Only in this way will it be possible to operationalize this fundamental human right. In his recent reports, the UN Special Rapporteur on the Right to the Highest Attainable Standard of Health began developing such an analytical framework. ${ }^{14}$ Based upon General Comment 14 of the UN Committee on Economic, Social and Cultural Rights, the framework "unpacks" the right to health in different contexts - in terms of freedoms, entitlements, nondiscrimination and equality, participation, international assistance and cooperation, monitoring and accountability, and so on. ${ }^{15}$

In this article, we apply this analytical framework to mental disabilities with a view to deepening our understanding of the right to health of persons with mental disabilities, as well as further developing the framework. We do not suggest the framework is fully developed yet; on the contrary, it should be regarded as work in progress. However, we hope that this article will lead to the framework being further refined and brought to bear upon the numerous other elements that together comprise the right to health, such as maternal health, environmental health, children's health, essential drugs, and so on. This, we suggest, is one indispensable way of contributing toward the operationalization of General Comment 14 and the right to health.

\section{THE DEBATE ON TERMINOLOGY}

When discussing mental health and mental disabilities, a complicating factor is the absence of agreement on the most appropriate terminology. Mental illness, mental disorder, mental incapacity, psychiatric disability, mental

14. See, e.g., Report of the Special Rapporteur on the Right of Everyone to the Enjoyment of the Highest Attainable Standard of Physical and Mental Health, U.N. ESCOR, Comm'n on Hum. Rts., 61st Sess., Agenda Item 10, U.N. Doc. E/CN.4/2005/51 (2005) [hereinafter Report of the Special Rapporteur 2005]; Report of the Special Rapporteur on The Right of Everyone to the Enjoyment of the Highest Attainable Standard of Physical and Mental Health, U.N. ESCOR, Comm'n on Hum. Rts., 60th Sess. U.N. Doc. E/CN.4/2004/49 (2004).

15. The Right to the Highest Attainable Standard of Health, General Comment No. 14, U.N. ESCOR, Comm. On Econ., Soc. \& Cult. Rts., 22nd Sess., U.N. Doc. E/C.12/2000/4 (2000) [hereinafter General Comment No. 14]. 
disability, psychosocial disability, intellectual disability, and several other terms are all used with different connotations and shades of meaning. Some of the terms reflect very important and sensitive debates, such as the discussion about a "medical model" or "social model" of functioning. ${ }^{16}$ Moreover, terminology has also evolved significantly in recent years and continues to do so. For example, intellectual disability, once commonly referred to as mental retardation or handicap, is now sometimes referred to as developmental disability.

In this article, we most frequently use the umbrella term mental disabilities. This includes disabilities arising from major mental illness and psychiatric disorders, e.g., schizophrenia and bipolar disorder; more minor mental ill health and disorders, often called psychosocial problems, e.g., mild anxiety disorders; and intellectual disabilities, e.g., limitations caused by, among others, Down's syndrome and other chromosomal abnormalities, brain damage before, during, or after birth, and malnutrition during early childhood. We use the term disability to refer to a range of impairments, activity limitations, and participation restrictions, whether permanent or transitory. ${ }^{17}$

Mental disabilities encompass a wide range of profoundly different conditions and notably two sets of conditions, psychiatric/psychosocial disabilities, and intellectual disabilities. Both sets, and many individual conditions, are distinct in their causes and effects. These differences have a crucial bearing on how the right to health must be interpreted and implemented if all persons with a mental disability are to enjoy their human rights on the basis of equality and nondiscrimination.

\section{A. Evolving Standards and Obligations}

Before focusing on the right to health, we wish to introduce some specialized, nonbinding international instruments and case law that have crucial relevance to our analysis. ${ }^{18}$

\section{Some Nonbinding International Instruments}

Adopted by the United Nations General Assembly in 1991, the Principles for the Protection of Persons with Mental Illness and the Improvement of Mental Health Care (MI Principles) contain detailed minimum human rights

16. See Who, international Classification of Functioning, Disability and Health (ICF) (2001).

17. Id.

18. See Gerard Quinn \& Theresia Degener, Human Rights and Disability, the Current Use and Future Potential of Human Rights Instruments in the Context of Disability (2002) (U.N. Doc. $\mathrm{HR} / \mathrm{PUB} / 02 / 1)$. 
standards concerning mental healthcare, which are applicable to persons with mental "illness" and anyone else in a mental healthcare facility. ${ }^{19}$ The twenty-five MI Principles include wide-ranging commitments relating to: standards of care and treatment, including the right to the least restrictive environment; the right to medication; consent to treatment; the treatment of minors and criminal offenders; the review of involuntary admissions; access to information; complaints, monitoring, and remedies; and others. The MI Principles take a strong and positive position with regard to community integration, recognizing, inter alia, the right of every person with a mental illness to be treated and cared for, as far as possible, in the community in which he or she lives. ${ }^{20}$ While some of the MI Principles recognize important rights and standards, others are controversial and are considered to offer inadequate protections, notably on the issue of informed consent.

Adopted by the General Assembly in 1993, the Standard Rules on the Equalization of Opportunities for Persons with Disabilities (Standard Rules) contain a broad range of commitments to ensure equal opportunities are available to persons with disabilities in all fields. The twenty-two detailed rules set out principles regarding responsibility, action, and cooperation with respect to: healthcare, rehabilitation, support services, awareness-raising, education, employment, family life, policymaking, and legislation. Significantly, they emphasize the right of persons with disabilities to participate, as well as the important role played by organizations representing persons with disabilities. ${ }^{21}$

In October 2004, state representatives, international organizations, and representatives of civil society, including persons with intellectual disabilities and their families, adopted the Montreal Declaration on Intellectual Disability (Montreal Declaration) at an international conference organized by the Pan-American Health Organization (PAHO) and the World Health Organization (WHO). ${ }^{22}$ In brief, the Montreal Declaration recognizes the human rights of persons with intellectual disabilities, including the right to health, and the interconnections between this and other rights. The Montreal Declaration represents an important step in standard setting because the rights and obligations surrounding intellectual disabilities had previously attracted little attention. ${ }^{23}$

19. Principles for the Protection of Persons with Mental IIIness and the Improvement of Mental Health Care (MI Principles), G.A. Res. 46/119, U.N. GAOR, U.N. Doc A/RES/46/119 (1991).

20. See id. princ. 7(1); see also Eric Rosenthal \& Leonard Rubenstein, International Human Rights Advocacy under the Principles for the Protection of Persons with Mental IIIness, 16 INT'L J. L. \& PSYCHIATRY 257 (1993).

21. See Standard Rules for the Equalization of Opportunities for Persons with Disabilities, G.A. Res. 48/96, R. 14(2), U.N. GAOR, 85th plen. mtg., U.N. Doc A/Res/48/96 (1993) [hereinafter Standard Rules].

22. Montreal Declaration, supra note 13.

23. A recent and welcome contribution to the literature is The Human Rights of Persons with Intellectual Disabilities: Different but Equal (Stanley S. Herr, Lawrence O. Gostin, \& Harold Hongju Koh eds., 2003). 
Other important instruments include the World Programme of Action concerning Disabled Persons, adopted by the General Assembly (1982); PAHO's Declaration of Caracas on Restructuring of Psychiatric Care (1990); and the Council of Europe's Recommendation 1235 (1994) on Psychiatry and Human Rights and Recommendation Rec(2004)10 on the Protection of the Human Rights and Dignity of Persons with Mental Disorder. ${ }^{24}$ At the heart of these commitments lies crosscutting human rights principles that underpin the realization of all human rights of persons with mental disabilities, including nondiscrimination and equality; participation; autonomy; and access to procedural safeguards, accountability mechanisms, and remedies. While elements of these instruments are helpful and detailed, some are inadequate and need revisiting, such as particular provisions in the MI Principles, which have proved controversial. ${ }^{25}$ Moreover, these instruments are not binding on states. The ongoing effort to draft the Comprehensive and Integrated International Convention on the Protection and Promotion of the Rights and Dignity of Persons with Disabilities is a welcome attempt to develop binding international law in the field of disability. ${ }^{26}$

In the meantime, the implementation of states' existing binding human rights obligations in the context of mental disabilities and mental health is being given inadequate attention. As a recent report by the SecretaryGeneral stated, "[A] more detailed analysis of the implementation of State human rights obligations in the context of mental health institutions would be desirable." ${ }^{27}$

Many provisions contained in the MI Principles, the Standard Rules, the Montreal Declaration, and other commitments relating to mental disabilities have profound connections to the right to health. Common sense dictates that, where appropriate, these specialized instruments should be used as

24. Adopted respectively by: World Programme of Action Concerning Disabled Persons, G.A. Res. 37/51, adopted 3 Dec. 1982, U.N. GAOR, 37th Sess., Supp. No. 51, U.N. Doc. A/37/51 (1982) [hereinafter World Programme of Action Concerning Disabled Persons]; Declaration of Caracas on the Restructuring of Psychiatric Care in Latin America (Regional Conference on the Restructuring of Psychiatric Care in Latin America, convened by PAHO/WHO, 11-14 Nov. 1990) [hereinafter Declaration of Caracas]; EUR. PARL. Ass. 10th Sitting, Rec. No. 1235 (12 Apr. 1994); Comm. Of Ministers, 896th Meeting, Rec. No (2004)10 (22 Sept. 2004).

25. See, e.g., World Network of Users and Survivors of Psychiatry, Position Paper on the Principles for the Protection of Persons with Mental Illness, available at www.wnusp. org/wnusp\%20evas/Dokumenter/positionpaper.html.

26. See Draft Comprehensive and Integral International Convention on the Protection and Promotion of the Rights and Dignity of Persons with Disabilities, Ad Hoc Committee on a Comprehensive and Integral International Convention on the Protection and Promotion of the Rights and Dignity of Persons with Disabilities, Working Group (New York, 5-26 Jan. 2004), U.N. Doc. A/AC.265/2004/WG.1 (2004).

27. Progress of Efforts to Ensure the Full Recognition and Enjoyment of the Human Rights of Persons with Disabilities: Report of the Secretary General, U.N. GAOR, 58th Sess., Agenda Item 119(b), I 43, 24, U.N. Doc. A/58/181 (2003). 
interpretive guides in relation to the binding, treaty-based right to health. This is certainly the mature view taken by the Committee on Economic, Social and Cultural Rights (CESCR). ${ }^{28}$ Equally, a range of conceptual frameworks and other insights arising from the treaty-based right to health provide useful guidance regarding the nonbinding international instruments relating to mental disabilities. Properly understood, the generalized international human rights treaties and specialized international instruments relating to mental disabilities are mutually reinforcing, as the remainder of this article endeavors to illustrate.

\section{The Development of Case Law in Regional Human Rights Systems}

A rich body of case law is developing at the regional level, helping to clarify and protect the human rights of persons with mental disabilities, including rights in healthcare contexts.

The European Court of Human Rights has issued several judgements relating to psychiatric/psychosocial disabilities and healthcare. ${ }^{29}$ Among its decisions, the Court has held that a psychiatric wing of a prison is not an appropriate place for "therapeutic" detention; ${ }^{30}$ that particular treatment and inadequate medical care and monitoring of mentally ill persons in detention may amount to inhumane and degrading treatment; ${ }^{31}$ and that detention for psychiatric reasons must involve a qualified psychiatric opinion. ${ }^{32}$

The Inter-American Commission on Human Rights has also considered cases concerning mental disabilities and healthcare. Victor Rosario Congo v. Ecuador concerned a mentally ill prisoner at a rehabilitation center, who had been denied psychiatric care, struck on the head, denied medical treatment, and left in isolation for forty days; he subsequently died. ${ }^{33}$ The

28. Persons with Disabilities, General Comment No. 5, U.N. ESCOR, Comm. on Econ., Soc. \& Cult. Rts., 11th Sess., ๆ ๆ 7(b), 34, U.N. Doc. E/C.12/1994/13 (1994) [hereinafter General Comment No. 5].

29. For a fuller discussion of the European Court's jurisprudence see, among others, Gostin \& Gable, supra note 12; O. Lewis, Protecting the Rights of People with Mental Disabilities: The European Court of Human Rights, 9 Eur. J. Health L. 293 (2002). For an overview of the approaches of the European Court and the Inter-American Commission, see Lawrence O. Gostin, International Human Rights Law and Mental Disability, HastingS Center Rep., Mar.-Apr. 2004, at 11, 12.

30. Aerts v. Belgium, App. No. 25357/94, Eur. Ct. H.R. (1998), I 46. The Court held that there

must be some relationship between the ground of permitted deprivation of liberty relied on and the place and conditions of detention. In principle, the "detention" of a person as a mental health patient will only be "lawful" for the purposes of subparagraph (e) of paragraph 1 if effected in a hospital, clinic or other appropriate institution.

31. Keenan v. United Kingdom, App. No. 27229/95, Eur. Ct. H.R. (2001).

32. Varbanov v. Bulgaria, App. No. 31365/96, Eur. Ct. H.R. (2000).

33. Rosario Congo v. Ecuador, Case No. 11.427, Inter-Am. C.H.R., Report No. 63/99, OEA/ Ser.L/N/II.102, doc. 6 rev. (1998). 
Commission found violations of the rights to physical integrity, life, and judicial protection under the American Convention on Human Rights. ${ }^{34}$ More recently, the Commission approved emergency measures to protect the lives and physical integrity of persons detained in a psychiatric hospital in Paraguay. The Commission also facilitated a friendly settlement between the applicants and the government of Paraguay that guarantees the rights of patients to live and receive mental healthcare in the community. ${ }^{35}$

The African Commission on Human and Peoples' Rights has only issued one decision focusing on mental disabilities, Purohit and Moore v. Gambia (2002). The case is, however, a landmark decision because it represents the first decision by an international mechanism finding a violation of the right to health on account of inadequate mental healthcare. ${ }^{36}$

Even though only Purohit and Moore v. Gambia involved a decision explicitly concerning the right to health, many decisions concerning other human rights, including the rights to life and liberty and the prohibition of inhuman and degrading treatment, offer indirect protections for particular freedoms and entitlements encompassed by the right to health and can inform interpretation of the right to health of persons with mental disabilities.

\section{B. Disabilities and the Human Right to the Highest Attainable Standard of Physical and Mental Health}

The International Covenant on Economic, Social and Cultural Rights (ICESCR) provides the central international protection of the right of everyone to the enjoyment of the highest attainable standard of physical and mental health. ${ }^{37}$ This human right is also enshrined in other international treaties, including the Convention on the Rights of the Child; regional treaties of the Americas, Europe and Africa; and over sixty national constitutions worldwide. ${ }^{38}$

34. Id. See also American Convention on Human Rights, signed 22 Nov. 1969, O.A.S.T.S. No. 36, O.A.S. Off. Rec. OEA/Ser.L/V/II.23, doc. 21, rev. 6 (1979) (entered into force 18 July 1978), reprinted in 9 I.L.M. 673 (1970).

35. Mental Disability Rights International, Historic Settlement Reached to Deinstitutionalize Mental Health System in Paraguay, available at www.mdri.org

36. Purohit and Moore v. Gambia, supra note 12.

37. International Covenant on Economic, Social and Cultural Rights [hereinafter ICESCR], adopted 19 Dec. 1966, G.A. Res. 2200 (XXI), U.N. GAOR, 21st Sess., Supp. No. 16, art. 12, U.N. Doc. A/6316 (1966), 993 U.N.T.S. 3 (entered into force 3 Jan. 1976).

38. Convention on the Rights of the Child, adopted 20 Nov. 1989, G.A. Res. 44/25, U.N. GAOR, 44th Sess., Supp. No. 49, art. 24, U.N. Doc. A/44/49 (1989) (entered into force 2 Sept. 1990), reprinted in 28 I.L.M. 1448 (1989); Additional Protocol to the American Convention on Human Rights in the Area of Economic, Social and Cultural Rights, Protocol of San Salvador, adopted 17 Nov. 1988, General Assembly of the Organization of American States, art. 10; African Charter on Human and Peoples' Rights, adopted 27 June 1981, O.A.U. Doc. CAB/LEG/67/3 Rev. 5 (entered into force 21 Oct. 1986), reprinted in 21 I.L.M. 58 (1982). For national constitutional protections of the right to 
For many years, the right to health was given little attention by the international human rights community. This situation changed in the 1990s, as greater attention was given to economic, social, and cultural rights generally, and as public health developments (notably the spread of HIV/AIDS) spurred increasing interest in the connections between health and human rights. ${ }^{39}$ In 1999, the Committee on the Elimination of Discrimination Against Women (CEDAW) adopted a General Recommendation on women and health. The following year, CESCR adopted a General Comment on the right to health. In 2002, the Commission on Human Rights decided to appoint a Special Rapporteur on the right to health. In 2003, the Committee on the Rights of the Child (CRC) adopted General Comments on HIV/AIDS and the rights of children, and on adolescent health and development in the context of the Convention on the Rights of the Child. ${ }^{40}$

CESCR's General Comment 14, which provides the most authoritative interpretation of the right to health, confirms that the right to health is not a right to be healthy. It is a right to facilities, goods, services, and conditions that are conducive to the realization of the highest attainable standard of physical and mental health. The General Comment articulates a framework of norms and obligations that make up the right to health. This framework includes, inter alia, freedoms, entitlements, nondiscrimination and equality, participation, international assistance and cooperation, and monitoring and accountability.

While General Comment 14 refers to a range of health issues, including mental healthcare, it adopts a generic approach to the right to health. Health consists of many dimensions. Moreover, different groups have varying health needs. The generic analytical framework first identified in General Comment 14 and subsequently elaborated in the Special Rapporteur's reports needs to be applied to specific health specializations, such as mental health, and to groups, such as persons with disabilities. This article seeks to apply this framework in the contexts of mental disabilities.

health, see Eleanor Kinney \& Brian A. Clark, Provisions for Health and Health Care in the Constitutions of the Countries of the World, 37 CornelL INT'L L.J. 285 (2004).

39. See Paul Hunt, Reclaiming Social Rights (1996); Health and Human Rights: A Reader (Jonathan M. Mann et al. eds., 1999).

40. Women and Health, General Comment No. 24, U.N. ESCOR, Comm. for Elim. of Discrim. against Women, 20th Sess., U.N. Doc. A/54/38/Rev. 1 (1999); General Comment No. 14, supra note 15; The Right of Everyone to the Enjoyment of the Highest Attainable Standard of Physical and Mental Health, adopted 22 Apr. 2002, U.N. ESCOR, Comm'n on Hum. Rts., U.N. Doc. E/CN.4/RES/2002/31 (2002); HIV/AIDS and the Rights of the Child, General Comment No. 3, U.N. ESCOR, Comm. on Rts. of the Child, 32nd Sess., U.N. Doc. CRC/GC/2003/3 (2003); Adolescent Health and Development in the Context of the Convention on the Rights of the Child, General Comment No. 4, U.N. ESCOR, Comm. on Rts. of the Child, 33rd Sess., U.N. Doc. CRC/GC/2003/4 (2003) [hereinafter General Comment No. 4]. 


\section{Progressive Realization and Resource Constraints}

The international right to physical and mental health is subject to progressive realization and resource constraints. ${ }^{41}$ This has a number of important implications. Put simply, all states are expected to be doing better in fiveyears time than what they are doing today (i.e., progressive realization). And what is legally required of a developed state is a higher standard than what is legally required of a developing country (i.e., resource constraints).

However, the international right to health also imposes some obligations of immediate effect. For example, it encompasses the right to be free from nonconsensual medical treatment. ${ }^{42}$ The enjoyment of this freedom is subject to neither progressive realization nor resource availability. Like the requirement of nondiscrimination, it has immediate application.

While many elements of the right to physical and mental health are subject to progressive realization and resource availability, there is a great deal that countries can do, even with very limited resources, toward the realization of the right. For example, even a country with limited resources can: include the recognition, care, and treatment (where appropriate) of mental disabilities in training curricula of all health personnel; promote public campaigns against stigma and discrimination of persons with mental disabilities; support the formation of civil society groups that are representative of mental healthcare users and their families; formulate modern policies and programs on mental disabilities; downsize psychiatric hospitals and, as far as possible, extend community care; actively seek assistance and cooperation that benefits persons with mental disabilities from donors and international organizations; and so on. ${ }^{43}$

This article includes many examples of what states-developing and developed — can do in relation to persons with mental disabilities and the right to health. Above all, however, it introduces a way of approaching, analyzing, and understanding mental disabilities through the prism of the right to health.

It is not possible in this article to provide a detailed analysis of the concepts of progressive realization and resource availability. For example, a state is obliged to use the maximum of its available resources toward the realization of the right to health. And progressive realization demands indicators and benchmarks to monitor progress in relation to mental disabilities and the right to health. An examination of these and other features of resource availability and progressive realization should be pursued on another occasion. ${ }^{44}$

41. ICESCR, supra note 37, art. 2 (1).

42. General Comment No. 14, supra note 15, ๆ 8.

43. WHO, World Health Report 2001, supra note 2, at 112-15.

44. For an approach to right to health indicators and benchmarks, see Interim Report of the Special Rapporteur of the Commission on Human Rights on the Right of Everyone 


\section{Freedoms}

The right to health contains both entitlements and freedoms, including freedom from discrimination. We give attention to nondiscrimination below. ${ }^{45}$ Freedoms - of particular relevance to the experience of individuals with mental disabilities-also include the right to control one's health and body. People, particularly women, with mental disabilities have been subjected to forced sterilizations, rape, and other forms of sexual violence, which is inherently inconsistent with their sexual and reproductive health rights and freedoms. Moreover, rape and other forms of sexual violence are psychologically, as well as physically, traumatic; and they negatively impact the right to mental health.

People with mental disabilities are also vulnerable to treatment without having given their informed consent. Decisions to administer treatment without consent sometimes occur because of ignorance or stigma surrounding mental disabilities and expediency or indifference on the part of staff. The giving of informed consent is an important process associated with the right to control one's health and body. "The [MI] Principles recognize that no treatment shall be given without informed consent. This is consistent with fundamental tenets of international human rights law, such as the autonomy of the individual, the right to health, and the prohibition against discrimination. But this core provision in the [MI] Principles is subject to extensive exceptions and qualifications. ... In practice, their combined effect tends to render the protection almost meaningless." 46

Several international human rights instruments allow for exceptional circumstances in which persons with psychiatric disabilities can be involuntarily admitted to a hospital or other designated institution. ${ }^{47}$ Clearly, such involuntary detention is an extremely serious interference with the right to liberty and security, as well as the "the right to live and work, as far as possible, in the community" and "the right to be treated and cared for, as far as possible, in the community." ${ }^{\prime 8}$ Because of its seriousness, international and national human rights law establishes numerous procedural safeguards

to Enjoy the Highest Attainable Standard of Physical and Mental Health, U.N. GAOR, 58th Sess., Agenda Item 117(c), U.N. Doc. No. A/58/427 (2003); Report of the Special Rapporteur on the Right of Everyone to the Enjoyment of the Highest Attainable Standard of Physical and Mental Health [hereinafter Report of the Special Rapporteur 2004], U.N. GAOR, 59th Sess., Agenda Item 105(b), U.N. Doc. No. A/59/422 (2004).

45. See infra § II.B.4(f).

46. See Report of the Special Rapporteur 2005, supra note 14, I 88. See also MI Principles, supra note 19, princ. 11. See also U.N. Doc. No. A/58/181, supra note 27, ๆ ๆ 34-42.

47. See European Convention for the Protection of Human Rights and Fundamental Freedoms, art. 5(1)(e), opened for signature 4 Nov. 1950, 213 U.N.T.S. 221, Europ. T.S. No. 5 (entered into force 3 Sept. 1953); MI Principles, supra note 19, princ. 16.

48. MI Principles, supra note 19, princs. 3, 7(1). 
in relation to such involuntary admission. Moreover, these safeguards are generating a significant jurisprudence, most notably in the regional human rights commissions and courts. ${ }^{49}$

In many countries, however, these procedural protections are not respected. In some countries, for example, persons with mental disabilities are involuntarily detained without the input of a qualified mental health practitioner or in inappropriate conditions. ${ }^{50}$ Also, they often do not have access to courts or tribunals to challenge involuntary admission.

Crucially, the freedom element in the right to health is subject to neither progressive realization nor resource availability.

\section{Entitlements}

The right to health includes an entitlement to a system of health protection, including healthcare and the underlying determinants of health, which provides equality of opportunity for people to enjoy the highest attainable standard of health. Crucially, care and support services-as well as medical attention-play a vital role in ensuring the health and dignity of persons with mental disabilities. ${ }^{51}$

CESCR's General Comment 5 on persons with disabilities gives attention to the right to health and health-related provisions of the Standard Rules and the Declaration on the Rights of Disabled Persons. The General Comment provides that:

States should ensure that persons with disabilities, particularly infants and children, are provided with the same level of medical care within the same system as other members of society. ${ }^{52}$

The right to physical and mental health also implies the right to have access to, and to benefit from, those medical and social services-including orthopaedic devices — which enable persons with disabilities to become independent, prevent further disabilities and support their social integration..$^{53}$

Similarly, such persons should be provided with rehabilitation services which would enable them "to reach and sustain their optimum level of independence and functioning." ${ }^{54}$

49. See generally Winterwerp v. The Netherlands, App. No. 6301/73, Eur. Ct. H.R. (1979); E. v. Norway, App. No. 11701/85, Eur. Ct. H.R. (1990); Gostin \& Gable, supra note 12; Lawrence O. Gostin, Human Rights of Persons with Mental Disabilities: The European Convention of Human Rights, 23 INT'L J.L. \& PSYCHIATRY 125 (2000); Lewis, supra note 29.

50. Varbanov v. Bulgaria, supra note 32, ๆ 47-53; Purohit and Moore v. Gambia, supra note 12, ๆ ๆ0, 45, 85; Congo v. Ecuador, supra note 33, ๆ 55-59.

51. Standard Rules, supra note 21, R. 2-4.

52. Id. R. 2, I 3.

53. See Declaration on the Rights of Disabled Persons, adopted 9 Dec. 1975, G.A. Res. 3447 (XXX), 30 U.N. GAOR Supp. (No. 34) at 88, I 6, U.N. Doc A/10034 (1975); World Programme of Action Concerning Disabled Persons, supra note 24, ๆ ๆ 95-107.

54. Standard Rules, supra note 21, R. 3. 
All such services should be provided in such a way that the persons concerned are able to maintain full respect for their rights and dignity. ${ }^{55}$

States should take steps to ensure a full package of community-based physical and mental healthcare and support services conducive to health, dignity, and inclusion. This package should include medication, psychotherapy, ambulatory services, hospital care for acute admissions, residential facilities, rehabilitation for persons with psychiatric disabilities, programs to maximize the independence and skills of persons with intellectual disabilities, supported housing and employment, income support, inclusive and appropriate education for children with intellectual disabilities, and respite care for families looking after a person with a mental disability twenty-four hours a day. In this way, unnecessary institutionalization can be avoided.

Augmenting interventions to ensure equality of opportunity for the enjoyment of the right to health will require training adequate numbers of professionals, including psychiatrists, clinical psychologists, psychiatric nurses, psychiatric social workers, occupational therapists, speech therapists, behavioral therapists, and caregivers, in order to work toward the care and full integration of individuals with mental disabilities in the community. General practitioners and other primary care providers should be provided with essential mental healthcare and disability sensitization training to enable them to provide front-line mental and physical healthcare to persons with mental disabilities.

As well as an entitlement to healthcare, the right to health includes an entitlement to the underlying determinants of health, including adequate sanitation, safe water, and adequate food and shelter. ${ }^{56}$ Persons with mental disabilities are disproportionately affected by poverty, which is usually characterized by deprivations of these entitlements. The conditions in psychiatric hospitals, as well as other institutions used by persons with mental disabilities, are often grossly inadequate from this point of view.

\section{Available, Accessible, Acceptable, and Good Quality}

Analytical frameworks or tools can deepen our understanding of economic, social, and cultural rights, including the right to health. One right-to-health framework that is especially useful in the context of policymaking is that health services, goods, and facilities, including the underlying determinants of health, shall be available, accessible, acceptable, and of good quality. ${ }^{57}$ This analytical framework, first articulated by CESCR in its General Comment on the right to health, applies to mental and physical healthcare, as

55. Comm. on Econ., Soc. \& Cult. Rts., General Comment 5, supra note 28, ฯ 34.

56. General Comment No. 14, supra note 15, ๆ 4.

57. Id. ๆ 12 . 
well as related support services. Each component has close synergies with international mental disability standards:

(a) Healthcare facilities, goods, and services must be available in adequate numbers throughout a state.

This includes adequate numbers of mental health-related facilities and support services, and adequate numbers of medical and other professionals trained to provide these services. For some persons with certain psychiatric disabilities, an adequate supply of essential medicines, including essential psychotropic medicines on WHO's List of Essential Medicines, should also be available. ${ }^{58}$

\section{(b) Accessibility has four dimensions.}

First, healthcare facilities, goods, and services, including support services, must be accessible physically and geographically -in other words, in safe physical and geographical reach of persons with disabilities. This has especially important implications for community-based care. Treatment and care are often provided far from the homes and workplaces of persons with mental disabilities, while there is also a lack of community-based support services. This lack of accessibility denies them their rights to live, work, and be treated and fully supported, as far as possible, in their communities. The importance of community-based treatment, care, and support is given significant emphasis in all modern standards concerning mental disabilities and can be seen as related to the movement to include mental health services as part of primary healthcare. The Declaration of Caracas, for example, promotes as its central message community-based service models integrated into social and healthcare networks. ${ }^{59}$ One of the twin objectives of the Inter-American Convention on the Elimination of All Forms of Discrimination Against Persons with Disabilities, adopted in 1999, is to promote the full integration of persons with disabilities into society. ${ }^{60}$ The MI Principles explicitly refer to "the right to live and work, as far as possible, in the community"; "the right to be treated and cared for, as far as possible, in the community"; and "the right to return to the community as soon as possible" where treatment and care is otherwise unavailable. ${ }^{61} \mathrm{WHO}$ also recommends that mental health services, including support services, be based in the community and integrated as far as possible into general health services, including primary healthcare, in accordance with the vital principle

58. WHO, Improving Access and Use of Psychotropic Medicines (2004).

59. Declaration of Caracas, supra note 24.

60. Inter-American Convention on the Elimination of All Forms of Discrimination Against Persons with Disabilities, adopted 7 June 1999, OAS Doc. AG/Res. 1608 (1999).

61. MI Principles, supra note 19, princs. 3, 7(1), 7(2). 
of the least restrictive environment. ${ }^{62}$ Second, health facilities, goods and services, including psychotropic drugs, must be economically accessible (i.e. affordable) to users. Mental healthcare and support services are often neither subsidized by the state, nor covered by health insurance, meaning that they can be unaffordable to most of those who need it.

Third, mental and physical healthcare services should also be accessible without discrimination on any of the prohibited grounds, such as sex and ethnicity. States may need to take affirmative action to ensure equality of access for all individuals and groups, such as ethnic and racial minorities in need of care and support. States should ensure that persons with disabilities get the same level of medical care within the same system as other members of society and that they do not face discrimination on the basis of presumptions of their quality of life and potential. ${ }^{63}$ For example, intellectual disability has been used as a ground to deny access to medical procedures such as organ transplants and life-saving treatments for newborn babies. ${ }^{64}$ But such reasoning is inherently incompatible with the right to access care on the basis of nondiscrimination.

A fourth dimension concerns the accessibility of information. This entitlement is often denied to persons with mental disabilities because they are wrongly judged to lack the capacity to make or participate in any decisions about their own treatment and care. Information on health (and other) matters, including diagnosis and treatment, must be accessible to persons with mental disabilities and to the parents of children with mental disabilities. ${ }^{65}$

\section{(c) Healthcare facilities, goods, and services must be culturally acceptable and respectful of medical ethics.}

Culture can have a strong influence on how individuals experience psychiatric disabilities and on care and support preferences. According to the MI Principles, "Every patient shall have the right to treatment suited to his or her cultural background." ${ }^{66}$ For example, mental healthcare and support services for indigenous peoples or racial and ethic minorities must be respectful of their cultures and traditions.

62. WHO, World Health Report 2001, supra note 2, at 89-91.

63. Report of the Special Rapporteur of the Commission for Social Development on Monitoring the Implementation of the Standard Rules on the Equalization of Opportunities for Persons with Mental Disabilities on his Third Mandate, 2000-2002, U.N. ESCOR, Comm'n for Soc. Dev., 40th Sess., Agenda Item 3(b), I 28, U.N. Doc. E/CN.5/2002/4 (2002) [hereinafter Report of the Special Rapporteur of the Commission for Social Development].

64. Marcia Rioux, On Second Thought, in Human Rights of Persons with Intellectual Disabilities, supra note 23, at 287.

65. Report of the Special Rapporteur of the Commission for Social Development, supra note 63, I 30.

66. MI Principles, supra note 19, princ. 7(3). 
(d) Healthcare facilities, goods, and services must be of good quality, including scientifically and medically appropriate.

This requires, inter alia, skilled medical and other personnel, evidence-based psychosocial interventions, scientifically approved and unexpired drugs, appropriate hospital equipment, safe and potable water, and adequate sanitation. In the context of mental disabilities, this means that, for example, health professionals should be provided with adequate mental healthcare training; and adequate sanitary facilities must be assured in psychiatric hospitals and other support services.

\section{(e) Respect, protect, and fulfill.}

Another useful analytical framework is that states have specific obligations under international law to respect, protect, and fulfill the right to health. While the framework outlined in the preceding paragraphs is especially helpful in the context of policymaking, the respect, protect, and fulfill framework is especially useful as a way of sharpening legal analysis of the right to health, including in relation to mental disabilities. ${ }^{67}$

The obligation to respect requires states to refrain from denying or limiting equal access to healthcare services and to underlying determinants of health for persons with mental disabilities. States should also ensure that persons with mental disabilities in public institutions are not denied access to healthcare and related support services or to underlying determinants of health, including water and sanitation. ${ }^{68}$

The obligation to protect means that states should take actions to ensure that third parties do not harm the right to health of persons with mental disabilities. For example, states should take measures to protect persons with mental disabilities, particularly women, adolescents, and other especially vulnerable groups, from violence and other right-to-health-related abuses occurring in private healthcare or support services.

The obligation to fulfill requires states to recognize the right to health, including the right to health of persons with mental disabilities, in national political and legal systems, with a view to ensuring its implementation. States should adopt appropriate legislative, administrative, budgetary, judicial, promotional, and other measures toward this end. ${ }^{69}$ For example, states should ensure that their population's right to the highest attainable standard of mental health and that the right to health of persons with mental disabilities are adequately reflected in their national health strategies, plans of action, and other relevant policies, such as national poverty reduction

67. General Comment No. 14, supra note 15, ๆ 33.

68. Congo v. Ecuador, supra note 33, ๆ $92,84$.

69. ICESCR, supra note 37, art. 2, ๆ 1; General Comment No. 14, supra note 15, ๆ 36. 
strategies and national budgets. ${ }^{70}$ Mental health laws, policies, programs, and projects should: embody human rights and empower people with mental disabilities to make choices about their lives; give legal protections relating to the establishment of (and access to) quality mental health facilities, as well as care and support services; establish robust procedural mechanisms for the protection of those with mental disabilities; ensure the integration of persons with mental disabilities into the community; and promote mental health throughout society. ${ }^{71}$ Patients' rights charters should encompass the human rights of persons with mental disabilities. States should also ensure that information about their human rights is made available to persons with mental disabilities and their guardians, as well as to other individuals who may be institutionalized in psychiatric hospitals. ${ }^{72}$

\section{(f) Nondiscrimination and equality.}

International human rights law proscribes discrimination in access to healthcare and the underlying determinants of health, as well as to the means for their procurement, on grounds including physical and mental disability and health status. ${ }^{73}$

Various forms of stigma and discrimination continue to undermine the realization of the right to health for persons with mental disabilities. For example, they often face discrimination in access to general healthcare services or stigmatizing attitudes within these services, which may dissuade them from seeking care in the first place. Stigma and discrimination within the community, schools, and workplaces can also act as a barrier to persons seeking social support, diagnosis, and treatment.

While the majority of families provide deeply caring and supportive environments for family members with mental disabilities, in some cases stigma may lead to inappropriate institutionalization of persons with mental disabilities against their wills, including sometimes in institutions that have inadequate facilities for treatment and care and where their dignity and other human rights are at risk. Decisions to isolate or segregate persons with mental disabilities, including by way of unnecessary institutionalization, are inherently discriminatory and contrary to the internationally recognized right to community integration. ${ }^{74}$ Segregation and isolation in itself can also generate stigmatization of mental disabilities.

70. WhO, Mental Health Policy, Plans and Programmes (2004).

71. See Who, who Resource Book on Mental Health, Human Rights and Legislation, supra note 8 .

72. General Comment No. 14, supra note 15, I 36; Standard Rules, supra note 21, R. 5(b); MI Principles, supra note 19, princ. 12.

73. See General Comment No. 14, supra note 15, ๆ ๆ 18-21.

74. Comm. on Econ., Soc. \& Cult. Rts., General Comment 5, supra note 28, I 15; Purohit and Moore v. Gambia, supra note 12, ๆ 30. 
The dissemination of information about mental disabilities and the human rights of persons with disabilities is an important strategy for combating stigma and discrimination. States have an obligation "[t]o provide education and access to information concerning the main health problems in the community," 75 which may include psychiatric disorders. The provision of human rights and disability awareness training for health workers, as well as staff in related sectors, is also essential for ensuring equal access to care and the respect of the human rights and dignity of persons with mental disabilities within care.

Under international human rights law, states not only have an obligation to prohibit discrimination, they also have a positive obligation to ensure equality of opportunity for the enjoyment of the right to health by persons with mental disabilities. For example, as well as being entitled to the same healthcare services as other members of society, the right to health gives rise to an entitlement of persons with mental disabilities to have access to, and to benefit from, those medical and/or social services that promote their independence and autonomy, prevent further disabilities, and support their social integration. ${ }^{76}$

This may demand special measures for particular groups. For example, states should ensure that adolescents with mental disabilities or psychosocial problems have access to necessary services that are sensitive to their needs. ${ }^{77}$ The Committee on the Rights of the Child has stressed the particular importance of paying particular attention to, among others, the special needs relating to the sexuality of adolescents with disabilities. ${ }^{78}$ Persons with intellectual disabilities often require specialized support services that are tailored to their individual needs. This might include habilitation, speech pathology, occupational therapy, physiotherapy, and behavioral therapy. Support is also essential for the families of persons with severe intellectual disabilities, given the acute demands that care and support can place on them.

Inappropriate resource allocation can lead to inadvertent discrimination. ${ }^{79}$ Crucially, the small budgetary allocations that most countries make for mental health and support services prevents persons with mental disabilities from enjoying their right to health on the basis of equality of opportunity.

\section{(g) Participation.}

Under international human rights law, the population is entitled to participate in health-related policy decisionmaking at the local, national, and interna-

75. General Comment No. 14, supra note 15, 9 44(d).

76. General Comment No. 5, supra note 28, 9 34; Purohit and Moore v. Gambia, supra note 12 , ๆ 81.

77. General Comment No. 4, supra note 40, I 22.

78. Id. I 35(c); Standard Rules, supra note 21, R. 9(2).

79. General Comment No. 14, supra note 15, I 19. 
tional levels..$^{80}$ The right of persons with mental disabilities to participate in decisionmaking processes that affect their health and development, as well as in every aspect of service delivery, is an integral part of the right to health and is affirmed in the Standard Rules and Montreal Declaration. ${ }^{81}$ Support may need to be given to those persons with mental disabilities who have difficulties making decisions or communicating preference.

It is essential that persons with mental disabilities and their representative organizations are involved at all stages of the development, implementation, and monitoring of legislation, policies, programs, and services relating to mental health and social support and to broader policies and programs, such as poverty reduction strategies, that affect them. States should affirmatively solicit their input. As providers of care and support, family members often have an important contribution to make in legislative and policy processes and in decisions concerning care. Involving mental healthcare users, their families, and representative organizations, and encompassing their perspectives in the design and implementation of all relevant initiatives, helps to ensure that the needs of persons with mental disabilities are met.

While the Standard Rules and Montreal Declaration recognize that it is particularly important to engage with representative organizations, such as mutual support and self-advocacy groups, mental disability organizations are not well-developed in many parts of the world. ${ }^{82}$ In order to ensure compliance with these international instruments, states should support the development and strengthening of advocacy groups of persons with mental disabilities. Recent literature from the WHO provides useful guidance for ministries of health in this respect. ${ }^{83}$

\section{(h) International assistance and cooperation.}

In addition to obligations at the domestic level, states have a responsibility deriving from, inter alia, ICESCR Article 2(1) and CRC Article 4 to take measures of international assistance and cooperation toward the realization of the right to health. This responsibility, which is particularly incumbent on developed states, also arises in the context of commitments made at recent world conferences, including the Millennium Summit and Millennium Development Goal $8 .{ }^{84}$

80. Id. ๑ 11.

81. supra note 21, R. 14, 18; Montreal Declaration, supra note 13, I 6.

82. Standard Rules, supra note 21, R. 14(2), 18; Montreal Declaration, supra note 13, ๆ $9(d)$.

83. WhO, Mental Health Policy and Service Guidance Package: Advocacy for Mental Health 5 (2003).

84. See Report of the Special Rapporteur 2004, supra note 44, ๆ 32-35, 42-46; Standard Rules, supra note 21, R. 21, 22 (on International Cooperation). 
States should respect the right to health in other countries, ensure that their actions as members of international organizations take due account of the right to health, and pay particular attention to helping other states give effect to minimum essential levels of health. ${ }^{85}$

Mental healthcare and support services are not normally a priority health area for donors. Where donors have provided financial assistance, this has sometimes supported inappropriate programs, such as rebuilding a damaged psychiatric institution that was first constructed many years ago, based on conceptions of mental disabilities that are now discredited. By funding such a reconstruction, the donor inadvertently prolongs, sometimes for many years, seriously inappropriate approaches to care and treatment. ${ }^{86}$ It is also unacceptable for a donor to fund a program that moves a psychiatric institution to an isolated location, making it impossible for the users to sustain or develop their links with the community. If a donor wishes to assist children with intellectual disabilities, it might wish to fund communitybased services to support children and their parents, enabling the children to remain at home, instead of funding new facilities in a remote institution that the parents can only afford to visit once per month, if at all. ${ }^{87}$

In accordance with their responsibility of international assistance and cooperation, donors should support a range of measures such as: supporting the development of appropriate community-based care and support services; supporting advocacy by persons with mental disabilities, their families, and representative organizations; and providing policy and technical expertise. Donors should ensure that all their programs promote equality and nondiscrimination for persons with mental disabilities. Some agencies are already giving attention to these issues. ${ }^{88}$ For example, the United States Agency for International Development (USAID) now requires all applicants for funding to demonstrate how their programs would be accessible to people with disabilities. ${ }^{89}$

A further aspect of international assistance and cooperation is the role played by international agencies in providing technical support. In recent years, excellent technical support has been carried out by organizations such as $\mathrm{WHO}$ and PAHO. ${ }^{90}$

85. General Comment No. 14, supra note 15, ๆ ๆ 38-45.

86. See, e.g., MDRI, Not on the Agenda: Human Rights of People with Mental Disabilities in Kosovo (2002).

87. Eric Rosenthal et al., Implementing the Right to Community Integration for Children with Disabilities in Russia: A Human Rights Framework for International Action, 4 Health \& Hum. RTs.: INT'L J. 83 (1999).

88. See, e.g., National Council on Disability, Foreign Policy and Disability (2003).

89. See Consolidated Appropriations Act, H.R. 4818, 108th Cong. $\$ 579$ (d) (2005).

90. WHO has also recently published many useful resources. See, e.g., WHO, supra note 8; Eric Rosenthal \& Clarence J. Sundram, The Role of International Human Rights in National Mental Health Legislation (2004). 


\section{(i) Accountability.}

Human rights empower individuals and communities by granting them entitlements and by placing legal obligations on others. Crucially, rights and obligations demand accountability. Accordingly, a human rights-or right to health-approach emphasizes obligations and requires that all duty-holders be held to account for their conduct. The acute vulnerability of some persons with mental disabilities to violations of their human rights makes it especially crucial that effective, transparent, and accessible monitoring and accountability arrangements are available and accessible. ${ }^{91}$

One of the most urgent steps that many states need to take to facilitate the realization of the right to health of persons with mental disabilities and other individuals who may be institutionalized in psychiatric hospitals is to enhance monitoring and accountability at the national and international levels.

At the national level, many countries have an absence of sustained and independent monitoring of mental healthcare. All too frequently, abuses of the right to health and of other human rights go unnoticed. This is the case not only in large psychiatric hospitals but also in community-based settings. The MI Principles emphasize that "[s]tates shall ensure that appropriate mechanisms are in force to promote compliance with these Principles, for the inspection of mental health facilities, for the submission, investigation and resolution of complaints and for the institution of appropriate disciplinary or judicial proceedings for professional misconduct or violation of the rights of a patient." ${ }^{\prime 2}$

This lack of surveillance is doubly problematic because persons with mental disabilities, especially those who are institutionalized but also those living in the community, are often unable to access independent and effective accountability mechanisms when their human rights have been violated. This may arise for various reasons, including: the severity of a condition; the absence of effective procedural safeguards, such as the provision of a personal representative for those deemed to lack legal capacity; a lack of access to legal aid; and a lack of awareness of their human rights and other entitlements. In some cases, there is no independent accountability mechanism in the first place.

Accountability procedures and remedies play a vital role in many respects, including for ensuring access to care and support services; enhancing participation; and protecting against discrimination and other rights abuses. An independent review body must be made accessible to persons with mental

91. For some comments on accountability, see Report of the Special Rapporteur 2004, supra note 44, ๆ 9 36-46.

92. MI Principles, supra note 19, princ. 22. 
disabilities or to other appropriate persons to periodically review cases of involuntary admission and treatment. ${ }^{93}$ It is imperative that the independent review body has the ability to overturn the involuntary admission if it finds continued confinement to be inappropriate or unnecessary. Persons with mental disabilities must be assured all the procedural safeguards spelled out in the MI Principles and elsewhere. ${ }^{94} \mathrm{~A}$ review body should also be empowered to consider cases in which admission has been sought, but denied.

Unless such an arrangement already exists, states should give urgent consideration to establishing an independent national human rights institution with a mandate that includes the promotion and protection of the human rights of persons with mental disabilities. The institution should have wide powers to carry out investigations, conduct public inquiries, and determine complaints. Properly resourced, it should conform to the Paris Principles and report annually to the national legislature..$^{95}$

At the international level, there is a range of detailed international standards concerning the human rights of persons with mental disabilities. However, a significant problem is lack of implementation. While the identification of international standards is important, the real goal remains effective implementation. Although international monitoring of the Standard Rules is entrusted to the Special Rapporteur of the Commission for Social Development on the monitoring and implementation of the Standard Rules, the MI Principles do not establish a monitoring or accountability mechanism.

International human rights treaties, including the ICESCR, CRC, CEDAW, CERD, and ICCPR, extend protections to persons with mental disabilities. ${ }^{96}$ However, as noted by Quinn and Degener in a recent report on the current and future use of UN human rights instruments in the context of disability: "The United Nations human rights treaty bodies have considerable potential in this field but have generally been underused in advancing the rights of persons with disabilities." ${ }^{\prime 97}$ States do not give significant attention to the right to health of persons with mental disabilities in their state party reports, although the situation is improving. The Commission on Human Rights has urged Governments to "cover fully the question of the human rights of persons with disabilities in complying with reporting obligations under the relevant United Nations human rights instruments." ${ }^{\prime 98}$ The Commission and disability experts have urged treaty bodies to give a greater focus to

93. Id. princ. 17.

94. Id. princs. 11, 18.

95. Principles Relating to the Status of National Institutions, adopted 20 Dec. 1993, G.A. Res. 48/134, U.N. GAOR, 48th Sess., annex, U.N. Doc A/48/49 (1993) (Paris Principles).

96. See QUinn \& DeGener, supra note 18.

97. Id. at 1 .

98. See, e.g., Human Rights of Persons with Disabilities, Res. 2000/51, adopted 25 Apr. 2000, U.N. ESCOR, Comm'n on Hum. Rts., I 11, U.N. Doc. E/CN.4/Res/2000/51 (2000). 
these issues, including in their discussions with states parties, Concluding Observations, and General Comments or Recommendations. ${ }^{99}$ Relevant civil society organizations, including representatives of persons with mental disabilities, should engage more with the treaty bodies, as well as the special procedures of the Commission on Human Rights. In time, the adoption and ratification of the comprehensive and integral international convention to promote and protect the rights and dignity of persons with disabilities will provide a further important avenue for monitoring and accountability.

\section{CONCLUSION}

Mental disabilities have been neglected on various fronts. Many states have devoted inadequate budgetary resources to mental health and support services and have failed to develop adequate policies, programs, and laws. Some states are responsible for systems of care within which the human rights of persons with mental disabilities are more likely to be violated than progressively realized. International organizations have traditionally given little focus to mental health, although $\mathrm{WHO}$ and $\mathrm{PAHO}$ are both making important strides toward redressing this imbalance. Donors have rarely adequately supported persons with mental disabilities in their policies or assessed policies for their impact on persons with disabilities, although there are some signs that this, too, is beginning to change. Civil society organizations, including associations of persons presently or formerly affected by mental disabilities, have made remarkable progress in advancing debates on issues of mental disabilities and human rights, in the face of widespread discrimination and stigmatization.

Moreover, significant progress is being made in understanding the issues and the development of appropriate support for persons with disabilities. This leads to greater opportunities for persons with mental disabilities to live a life of dignity, and to ensure, to the maximum extent, their autonomy, participation, and integration in society. Increased attention to mental disabilities by policy and lawmakers is vital if these developments are to be used to support the realization of the human rights of persons with mental disabilities, including their right to health.

There is still a need for most, if not all, states to enhance and amplify policy and legal initiatives relating to mental disabilities, with the objective of guaranteeing the human rights of persons with mental disabilities. In appropriate cases, $\mathrm{WHO}$ and PAHO can provide technical cooperation; and the financial support of donors should be sought. States should devote a much

99. Id.; QUinn \& DeGener, supra note 18 , at $4-5$. 
more significant part of their health budgets to mental health and use these funds for prevention efforts, as well as for community-based treatment and care. Monitoring of mental healthcare and support services, as well as strong accountability mechanisms that provide proper opportunities for persons with mental disabilities to seek redress, must also be given greater attention. A human rights approach, including participation, autonomy, dignity, and inclusion, should guide all these and other relevant actions. 